\title{
Rebuilding Farm-forestry Interface: An Opportunity to Address Food Security and Environmental Sustainability in Nepal
}

\author{
Krishna Prasad Paudel ${ }^{1, *}$, Yuba Raj Subedi ${ }^{1}$, Sujata Tamang ${ }^{1,2}$ \\ ${ }^{1}$ ForestAction Nepal, Nepal \\ ${ }^{2}$ School of Social Sciences, University of New South Wales Sydney, Australia
}

Copyright $\bigcirc 2016$ by authors, all rights reserved. Authors agree that this article remains permanently open access under the terms of the Creative Commons Attribution License 4.0 International License

\begin{abstract}
The farm and forestry divide was a slip of development strategy of the dominant reductionist views about people and nature. The separate policies, institutional as well as bio-physical boundaries of farm and forestry and the divided roles of the farmers and service providers has resulted the greater extent of failure in both the agriculture as well as forestry to improve the local food system, income/employment and the fragile ecosystem. The community based forestry, traditionally with significant buffering role to farm and forest interface, was dragged and boxed into orthodox forestry domain - leading this failure. This paper critically examines the scope of rebuilding farm forest relations for food security and environmental sustainability analyzing the historical trajectories of farm forest divide. It analyzes the potential of community forestry to bring them together for food security and environmental sustainability. We argue that a transformative agro-forestry approach must adapt in view with to address the key issues of food security, local livelihoods and environmental degradation including climate change hazards. In specific, relatively less labour intensive low input agro ecological approach of producing food, wood and good (public) together can be successfully reintroduced. In the changing socio-economic and environmental context, rethinking on rebuilding farm forestry interface is imperative, and the transformative agriculture can play a significant role in bridging these two systems towards more productive, viable and sustainable solutions for future. However, it demands very genuine initiative towards integrating farm with forest, productivity with sustainability and equity of resources. Along with the appropriate agroforestry technology, the effort should also be in place to transform policies and institutions that address the issues of resource access and ownership.
\end{abstract}

Keywords Forced Divide, Agroforestry, Transformative Agriculture, Food Security, Livelihoods

\section{Introduction}

Community Forestry (CF) practices in Nepal, with its journey of more than three decades, has been established as a prominent approach for the conservation and restoration of the degraded forest lands. However, as several studies show, one of the twin goals - actual contributions of CF to improve the livelihoods of poor and marginalized is still limited (1-3). While the debate has initiated among scholars and politicians to bring more than 18000 community forestry user groups (CFUGs) into active forest management to enhance the food security and livelihoods of forest-dependent poor users. These 18,000 plus CFUGs are managing over 1.4 million hectares of forest land. However, isolated from farming practices within its biophysical as well as social boundaries, community forestry practice is now trapped in conservation approach. Therefore it needs to be better understood before seeking its potential contribution to food security and livelihoods.

This paper intends to look into the historical development of community forestry practice beyond agroforestry and seeks to bring the debate on sustainable management of natural resources through integrated farm forest system that could address the issue of food security, migration and climate change in the changing context. This is based on the desk review of relevant literatures, field observation interaction and reflection, and authors own experience. This paper is divided into four major sections- Introduction on farm forest interface, description on historical trajectories, key finding and conclusion.

\section{Farm Forest Interface: A Broader Picture}

It is not a surprise that many Nepali farmers are combining forestry and agriculture on their land from generations. Forest species are integrated in farms which provide valuable 
products to the farmer for their own household consumption or to feeds their livestock that they rear. The standing trees are source of nutrient recycling, biodiversity conservation, erosion control and reduction of level of carbon dioxide in the atmosphere. In fact, forests provides almost $90 \%$ of the total fuel wood demand and more than $50 \%$ of the fodder requirement to feed livestock, such as buffalo, goat in mid hills (4). Michon et al. (5) suggested that at the local level, it is not that easy to delineate between forests, fallows and agroforestry in terms of vegetation structure and composition where forests are fully integrated into agriculture activities and most local forest managers are farmers as well.

Nepalese farming systems heavily rely on forest resources such as leaf litter, fodder for net transfer of fertility from stall-fed animals to cropland in the forms of organic manure (6) . 'Agroforestry' in its term of agriculture and forestry together is a vital source of income and employment of the country's economy. It contributes 33\% to GDP and $90 \%$ of rural population is dependent on agriculture for their subsistence livelihoods $(7,8)$. In rural Nepal, livestock, forest, and agriculture practices are webbed in such a way that separation of these three sectors at field level is impractical.

Yet, despite of this tradition and obvious connections between forest and agriculture, there has been a very little effort at policy arena to bring these sectors closer. Surprisingly, both sectors are developing long term strategies without informing each other.

The failure of integrating farm and forest primarily relate with the misconception underlying the current agriculture practice of mid hills of Nepal. Misunderstanding of traditional integrated farming system as the subsistence agriculture at policy level and indicating it as a major constraint in agriculture development, it has gradually increased the distance between farm and forest thereby making both less productive. In one hand, green revolution agriculture is depleting soil nutrient level (9) and in other, the commercial marketing of the forests are responsible for degrading forest lands itself $(10,11)$.

\section{Historical Trajectories of Farm Forest Divide in Nepal}

The agroforestry practice in the mid-hills of Nepal has a long history where integration of crops, livestock and forestry is managed for food security and livelihoods (12-14).

Community forestry was re-conceptualised as a potential strategy to meet the needs of local people (15) and protect the environment against degradation (16) during 1970s. Initially community forestry was defined as one of the agroforestry approach (12). This can be seen as it gave birth to several popular terms ending with "forestry" such as social, farm, rural, community and agro (17-19). These are used in different contexts and specialists maintained the distinctions as per their interests and defined in precise technical terms
(20). Among these, social forestry is defined as an umbrella term - the practice of planting or using trees to pursue social objectives through delivery of benefits to the local people (13).

These distinct categories have huge implication on promoting agroforestry, in particular the divide of the institutional landscape - the target communities, the institutional involvement and the long term programmes, policies and strategic approaches.

There is a different meaning and perception of agroforestry as well. Many institutions including international centre for agroforestry (ICRAF) takes it as simply a technological approach to enhancing the productivity of natural resources (14). Following this technological point of view, foresters view it as an approach to planting trees and other forest species on farm land. On the other hand, the agriculturists generally view it as an integrating farm, livestock and forestry to enhance the agriculture production. This view contradicts with the ongoing policies and practices, which believes in modernisation of agriculture through high input monoculture (21). This understanding of modern agriculture disintegrated the concept of agroforestry and compartmentalised it in two sectors - agriculture and forestry, and thus creating strong boundaries of separation between them.

The Nationalization of Forest and green revolution agriculture was the beginning of the divide between farm and forest. This was accelerated with the parallel process of 'systematic management of Terai ${ }^{1}$ forest and planning for conservation $(22,23)$ and 'planned resettlements in Nepal's Terai' (24). Furthermore, it was sustained with urban development in 60 s where large scale of timber harvest was done to supply timber and other forest products to the city centre. At the same time, agricultural land was expanded to meet the need of these growing city centers (25).

The timber for construction and electricity poles were mainly supplied from Terai forests (26). This led to massive deforestation in some of the Terai region, where agriculture was extended. This cyclic tendency continued, making conservation a major agenda of forestry sector.

Following the suggestion of UN forest experts to 'consult people for any proposed solutions' for forest degradation (27), initially, local forests were handed over to local Panchayat ${ }^{2}$, which formed the basis of handing over community forests to users in $90 \mathrm{~s}$.

On the other hand, agricultural land was expanded in Terai with the settlement program. This led to more intensive monoculture with the flow of hybrids, chemicals and pesticides $(24,25)$. This was followed by promotion of private forests with the aim to reduce the pressure on forest for forest product (28). These sectoral development approaches to farm and forest was reinforced by scientific forest management and green revolution agriculture schooling.

1 Terai is the plain regions of nepal

2 A village council 
In this divide, Himalayan degradation was the central argument $(16,29)$. It was argued that if immediate actions are not taken, this region will turn into a desert by 2000 (30). It was claimed that the main causes were livestock, deforestation and population pressure. This statement was not developed through empirical studies but rather external expert's understanding which was 'a sort of hegemonic discourse, and one that has become embedded in broader global discourses on development, environmental change, and population'(27).

On the other hand, food security was a major concern, so subsistence agriculture was blamed for not having enough food production. Commercialization of agriculture was seen a way forward. Therefore, green revolution agriculture was introduced in extended Terai lands. This was done in new and expanded area in Terai region which is close to the border of India - where green revolution was practiced massively.

Forest degradation was seen as cause of overpopulation and livestock including subsistence agriculture practices (16). This led to a misguiding problem statement and its solution separating farm and forests. The introduction of community forestry based on group approach reinforced separations further as farmers became users of the forestry not the owners of the agroforestry practices.

This divide was deepened with various programs and practices. In forestry, forest restoration and environment sustainability was major concern but it was coined as twin goal- environment and livelihoods to ensure local participation in forest conservation. In agriculture clean monoculture was introduced as the new approach to agriculture. Private forest was introduced with massive plantation in Terai and grass and fodder plantation in hills and mountain.

Separate Forestry sector master plan and Agriculture Perspective Plan certified this divide. CF with its policy and institutional arrangements [forest act 1993 and community forestry regulation 1995] has become a leading forestry program. Neither of these documents speak about integrating farm and forest, rather specifies the core agenda of conservation and commercial agricultural production (31).

Since 90s, there has been a dramatic shift in positions of Community Forestry and agro forestry. CF is operating with full recognition as program of forest department has been receiving support from all major donors, formed 18000 plus user groups, with user federation and community forestry division. However, agroforestry did not receive any attention from government as well as donors as it was taken as traditional subsistence agriculture practice and merely an arena for research practice. Trees on farms are taken as weed in modern clean agriculture. This led to drastic reduction of livestock number in hills and mountain, making agricultural lands less productive and less fertile in the mountainous regions. At the same time, private forestry was discouraged by regulations which do not allow harvesting trees without district forest officer's permission (32).

According to some scholars, the introduction of
Community forestry widened its scope to benefit all categories of forest dependent communities. Community forestry broadened its definition as a village-level forestry activity on communal/common land that community people collectively decide and implement the planning, management and harvesting of forest products, and getting livelihoods benefit and food security including other socio-economic and ecological benefits from the forest (33).

However, the following quote from one of the field facilitators who had also been engaged in forming CF groups and supporting them in the mid hills of Nepal also provides an interesting insight on how community people perceive forestry group:

"When we visited a village to form a community forest user group, we initially explained about the benefits of community forestry and the processes and legal provisions. The villagers appeared to be enthusiastic and actively participating in the meeting. Later, when we told them that they needed to identify the boundary of the forest area to proceed formally with forming the group and applying for community forest status. One of the senior members of the village said to us, 'Okay, if you want to form a CFUG, take that forest over there' showing us a degraded area of forest. He pointed to the good natural forest near the village and said 'this forest is ours and we do not want [your organization] to turn it into a community forest'. Only then did I understand to some extent how local people perceive us and the community forestry programme in real sense" (field facilitator's experience quoted in (3).

Despite the potentials, the promotion of agroforestry has never been given high priority in the country's agricultural and forestry development policies and plans. There was a big shift in agroforestry practices after introduction of community forestry. Along with this, the introduction of monoculture in agriculture - clean sweep agriculture and introduction of reductionist bio-diversity conservation approaches, shifting from the wider nature conservation pushed back the spirit of agroforestry in all front. Particularly, in Terai, young farmers of below 35 years, they cannot think about agriculture without hybrids, chemicals and pesticides as there was use of these chemicals and pesticides before them.

These initiatives resulted in developing the framework of current community forestry and leasehold forestry programmes.

The diagram below, Adopted from (31), shows the evolution of community forestry practices. Initially all the agroforestry activities were initiated by donor funded field projects. Interestingly, there is no continuity of these initiatives once the forest areas are handed over to communities in the name of users in community forestry and leasehold forestry. Currently, community forestry and leasehold forestry are the ongoing programmes under the banner of agroforestry but both of them are driven more by forest management perspective than the integrated system of agroforestry (31). 


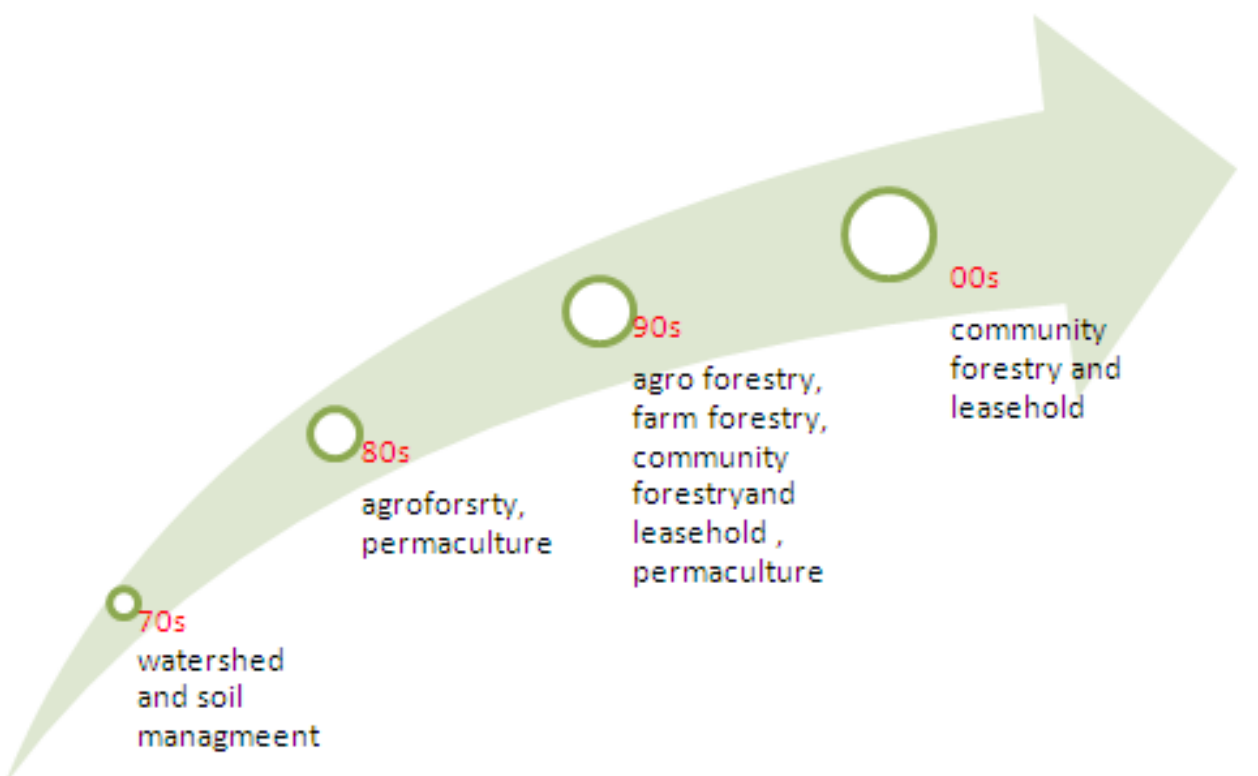

However, farmers through experience have developed appropriate local/indigenous knowledge base about tree-crop interaction (34).There are also small scale scattered efforts that have given consideration to agroforestry such as organic farming, Permaculture, planting trees on farmlands, fodder trees in forest and Non Timber Forest Products (NTFPs) promotion in both forest and farm land.

\section{Discussion: Rethinking on Reintegration}

In summary, the key interventions such as planned development intervention, planned re-settlement and expansion of agricultural lands in Terai, green revolution agriculture and agriculture perspective plan distanced agriculture from forestry. Similarly, the key intervention in forestry sector such as nationalization of private forests, urban migration, discourses created by theory of Himalayan degradation, Panchayat forest, forestry sector master plans led to further distance the forestry from farming systems.

It can be said that the farm and forestry divide was a slip of development strategy of the dominant reductionist views about people and nature. The separate policies, institutional as well as bio-physical boundaries of farm and forestry and the divided roles of the farmers and service providers has resulted the greater extent of failure in both the agriculture as well as forestry to sustain the local food system, income/employment and the fragile ecosystem. The community based forestry, traditionally with significant buffering role to farm and forest interface, was dragged and boxed into orthodox forestry domain leading this failure. This divide was facilitated by reductionist approach of understanding land, water, forest, agriculture and energy. The farmers reduced to users and service providers and technical support reduced to administrator and consultancy services respectively. Separate policies and institutional mechanisms were devised to facilitate separate regimes with particular interests of donors, technical experts, and politicians and government official with their techo-bureaucratic mindsets (35).

This is high time we rebuilt farm forest relations for food security and environmental sustainability. The historical trajectories of farm forest divide were built with specific environmental concerns of external experts who concluded their recommendations within their limited insights of the situation at grassroots.

The competition for land as well as the imperative to address climate change effects through appropriate agro-ecological management system reinforced the need for broader conceptualisation of agroforestry beyond these technical approaches of community forests. It also compelled to bring farm and forest together for sustainable natural resource management system that can deal with the food security, local livelihoods as well as agro-ecological issues in a collective manner.

We see a high potential of community forestry to transform into agroforestry practices beyond forestry regime. While transforming community forestry regime, a transformative agro-forestry approach must adapt in view with to address the key issues of food security, local livelihoods and environmental degradation including climate change hazards. Specific consideration must be given to reintroduce relatively less labour intensive and low input agro ecological approach for producing food, wood and good (public) together.

Once again the recent global debate on food security and climate change is pushing agroforestry agenda as a potential approach and many of the institutions are now revisiting their approaches. The mega initiatives such as Global Agriculture and Food Security (GAFSP) and feed the future programmes are some of the examples in this context. 


\section{Conclusions and Way Forward}

In the changing socio-economic and environmental context, rethinking on rebuilding farm forestry interface is imperative, and the transformative agriculture can play a significant role in bridging these two systems towards more productive, viable and sustainable solutions for future. However, it demands very genuine initiative towards integrating farm with forest, productivity with sustainability and equity of resources. Along with the appropriate agroforestry technology, the effort should also be in place to transform policies and institutions that address the issues of resource access and ownership.

The way forward is to bring closer these two systems reintegration. Agriculture should be viewed from agro-ecological perspective with core activities of biodiversity conservation, maintenance of soil fertility and low input agriculture practices. In forestry, agroforestry system should rebuild considering the key challenges of food security, climate change and productive use of fertile forest lands.

\section{REFERENCES}

[1] Mahapatra R. Betrayed": Nepal's forest bureaucracy prepares for the funeral of the much-hailed community forest management programme. Down to Earth. 2001;9(22):20-2.

[2] Kanel KR, editor Twenty-five years of Community Forestry: Contribution to Millennium Development Goals ‘ Twenty-five Years of Community Forestry Proceedings of the Fourth National Workshop on Community Forestry; 2004.

[3] Paudel KP. Knowledge, power and practice in community forestry: a case from Nepal's Terai: The University of Reading; 2009.

[4] Shrestha BB. Fuelwood harvest, management and regeneration of two community forests in Central Nepal. Himalayan Journal of Sciences. 2005;3(5):75-80.

[5] Michon G, De Foresta H, Levang P, Verdeaux F. Domestic forests: a new paradigm for integrating local communities' forestry into tropical forest science. Ecology and Society. $2007 ; 12(2)$.

[6] Mohan KB, Krishna RT, Gandhiv K, Shrikrishna G, Shankar $\mathrm{T}$, Bandana B. Farmers dependency on forests for nutrients transfer to farmlands in mid-hills and high mountain regions in Nepal (case studies in Hemja, Kaski, Lete and Kunjo, Mustang district). International Journal of Biodiversity and Conservation. 2014;6(3):222-9.

[7] CBS. nepal living standards survey 2010/11 Kathmandu: Central Bureau of Statistics; 2011.

[8] CBS. Agriculture Census,2013. Kathmandu: Central Bureau of Statistics, Government of Nepal; 2013.

[9] Deshar BD. An overview of agricultural degradation in Nepal and its impact on economy and environment. Glob J Econ
Social Develop. 2013;3(1):1-20.

[10] DeFries RS, Rudel T, Uriarte M, Hansen M. Deforestation driven by urban population growth and agricultural trade in the twenty-first century. Nature Geoscience. 2010; 3(3): 178-81.

[11] Boucher D, Elias P, Lininger K, May-Tobin C, Roquemore S, Saxon E. The root of the problem: what's driving tropical deforestation today? The root of the problem: what's driving tropical deforestation today? 2011.

[12] Gilmour DA, Fisher RJ. Villagers, forests, and foresters: The philosophy, process, and practice of community forestry in Nepal. 1991.

[13] Hobley M. Participatory forestry: the process of change in India and Nepal: Overseas Development Institute (ODI); 1996.

[14] Garforth CJ, Malla YB, Neopane RP, Pandit BH. Socioeconomic Factors and Agro-Forestry Improvements in the Hills of Nepal. Mountain Research and Development. 1999;19 (3):273-8.

[15] Mahat T, Griffin D, Shepherd K. Human Impact on Some Forests of the Middle Hills of Nepal Part 2. Some Major Human Impacts before 1950 on the Forests of Sindhu Palchok and Kabhre Palanchok. Mountain Research and Development. 1986:325-34.

[16] Eckholm E. Losing Ground Enviromental Stress and World. 1976.

[17] Tamale E, Jones N, Riddihough I. Technologies related to participatory forestry and subtropical countries. World Bank Technical Paper No. 299. World Bank Group, Washington, DC (United States); 1995.

[18] Nair PR. An introduction to agroforestry: Springer Science \& Business Media; 1993.

[19] Foley G, Barnard G. Farm and Community Forestry. Earthscan Energy Information Programme Technical Report No. 3. International Institute for Environment and Development, London. 1984;236.

[20] Barraclough SL, Ghimire KB. Forests and livelihoods: the social dynamics of deforestation in developing countries 1995 .

[21] APROSC, JMA. Nepal Agriculture Perspective Plan 1995/96-2014/15 A.D. Kathmandu: Agricultural Projects Services Centre and John Mellor Associates; 1995.

[22] Bajracharya M. Forests in Nepal: An introduction. Berkeley, University of California. 1986.

[23] Skerry CA, Moran K, Calavan KM. Four decades of development: the history of US assistance to Nepal, 1951-1991: United States Agency for International Development; 1991.

[24] Elder JW, Ale M, Evans MA, Gillespie DP, Nepali RK, Poudyal SP, et al. Planned resettlement in Nepal's Terai. University of Wisconsin, Madison, WI. 1976.

[25] Feldman D, Fournier A. Social relations and agricultural production in Nepal's Terai. The Journal of Peasant Studies. 1976;3(4):447-64.

[26] Regmi RR. Deforestation and rural society in the Nepalese 
Terai. Occas Pap Sociol Anthropol. 1994;4:72-89.

[27] Guthman J. Representing Crisis: The Theory of Himalayan Environmental Degradation and the Project of Development in Post - Rana Nepal. Development and Change. 1997;28(1):45-69.

[28] Acharya KP, Adhikari J, Khanal D. Forest tenure regimes and their impact on livelihoods in Nepal. Journal of Forest and Livelihood. 2008;7(1):6-18.

[29] Ives JD, Messerli B. The Himalayan dilemma: reconciling development and conservation: Psychology Press; 1989.

[30] Messerschmidt DA. Conservation and society in Nepal: Traditional forest management and innovative development. Lands at Risk in the Third World: Local-Level Perspectives. 1987:373-97.

[31] Paudel KP, Dahal D, Shah R. Abandoned Agriculture Land in Mid Hills of Nepal: Status, Causes and consequences.
Kathmandu: ForestAction Nepal and IUCN Nepal; 2012.

[32] Pandit BH, Ojha H, Shrestha KK, Nuberg I, Amatya SM. Why Cannot Local Communities Do Forestry Business? Analysis of Barriers in the Value Chain of Private Forestry Products in Nepal. Sixth national Community Forestry Conference; June 16-18, 2014; Kathmandu, Nepal.2014.

[33] Springate-Baginski O, Soussan J, Dev O, Yadav N, Kiff E. Community forestry in Nepal: Impacts on common property resource management. 1999.

[34] Thapa B, Sinclair FL, Walker D. Incorporation of indigenous knowledge and perspectives in agroforestry development. Agroforest Syst. 1995;30(1-2):249-61.

[35] Ojha HR. Techno-bureaucratic doxa and challenges for deliberative governance: The case of community forestry policy and practice in Nepal. Policy and Society. 2006;25(2):131-75. 